\title{
Achieving Work-Life Balances through Flexible Work Practices
}

\author{
Binod Ghimire, Ph.D. \\ Lecturer, Nepal Commerce Campus, T.U. \\ e-mail: bin.ghimire@gmail.com
}

\begin{abstract}
The paper aims to examine flexible work practices and employees' perception of work-life balance. The main purpose of this study is to understand the relationship between flexible work practice and work-life balance. The study is descriptive and co-relational. It is based on the perceptions of employees and includes the questionnaire to 160 employees of service-based organizations working on a different level at Kathmandu Valley. The sample consisted of managerial and nonmanagerial employees who were interested to participate in this study. It is found that employees feel that a flexible work schedule is the right kind of system for their kind of job and they prefer flexibility at work. Flexibility work practice was found to have a positive impact on the employees. It made them more responsible as they were able to manage time at work and fulfill the personal commitment. This paper is useful to academicians and organizations to understand the impact of FW practices on work performance. The findings in this study would help managers and organizations in Nepal to formulate flexible work schedules to improve the work-life balance of human resources working in the organization.
\end{abstract}

Keywords: Flexibility work arrangements, Employees, Work-life balance

\section{Introduction}

The globalization of the world economy and the growth of e-commerce have driven the work schedule in a new perspective. It has made the notion of a 40 to 48 -hour workweek obsolete. With the demand for more exposure and need for work results, there seems pressure in work resulting in greater employee stress, less satisfied employees, loss of productivity, and higher turnover. All these results are costly for companies. In this connection, greater flexibility in the workplace would have some positive effects as workers would have choice and control to achieve a better fit of their hours worked to their preferences. (Cooper \& Burke, 2008)

Flexible working hours have recently gained a lot of attention from organizations and scholars as family-friendly policy. Nowadays, organizations are trying to incorporate a culture of trust by offering employees flexibility in the workplace. Some researchers argue that flexible working practices facilitate work-life balance, and with shifting family patterns such practices are beneficial for both women and men. FWAs are useful for achieving the more efficient use of human resources (HR) because they provide an opportunity to allocate employees and their time depending on the nature of work that has to be done (Berker, Morley, Tiernan, Purtill, \& Parry, 2017). It is used to recruit talented employees and retain them with higher satisfaction and productivity. Some organizations are adopting FWA with Results-Only Work Environment (ROWE) so that employees get the job done being fully responsible to achieve the desired results. The rationale of this arrangement is to let employees focus on productivity, rather than whether they 


\section{Problem Statement}

Workers are attracted to flexible arrangements because they believe the freedom they enjoyed would help them more done. There is an implicit but clear argument, too: Employees often feel they would enjoy working at home more than having to drive through rush hour traffic to get to the office (Darley, 2017). With this consideration, this research aims to analyze the impact of flexible working arrangement on employees' job outcome. Thus, it takes into account and tries to answer the following question:

- What is the impact of the flexible working arrangement upon employee's work-life balance?

\section{Objectives of the Study}

The main objective of this study is to find out the impact of flexible working arrangements upon employees' job outcomes in private companies in Kathmandu Valley. To achieve the basic objective, specific objectives are formed as follows:

i. To examine the relationship between flexible working arrangements and work-life balance.

ii. To identify the impact of flexible working arrangements on work-life balance.

\section{Research Methods}

This study has employed a descriptive and correlation research design. Primary data is used to collect information about the perception of FWA and work-life balance. Self-administered questionnaires have been used to collect the information. This study is based on 160 employees from service-based organizations. The convenience sampling technique was used to identify the respondents and collect the responses. The respondents like officers, managers, senior-junior assistants were recorded accordingly to their availability in organization and convenience. Structured questionnaires have been used as a tool for examining the level of commitment prevailing in the different sectors under the study.

\section{Reliability Test}

The Cronbach's Alpha was used to assess the reliability of constructs; job security and employee commitment. The final output of the reliability test is shown in Table 1.

Table 1

Reliability Test

\begin{tabular}{lccc}
\hline Construct & Minimum reliability index & Cronbach alpha & Results \\
\hline Perception of FWA & 0.6 & 0.765 & Reliable \\
Work-life balance & 0.6 & 0.889 & Reliable \\
\hline
\end{tabular}

Table 1 show that both constructs were higher than significance level of 0.7 . Therefore, it can be concluded that all the constructs used for this study were highly reliable. There is no need to drop any of the items from all constructs since the original cronbach's alpha obtained for every construct is rather high i.e. FWA recorded 0.765 , work-life balance recorded 0.889 .

\section{Demographic Analysis}

This section involves demographic information about the respondents from different organizations undertaken in this research. It involves information about number of respondents participated from each organization, gender of respondents, age of respondents, educational qualification, job tenure, position and their time involvement while in their respective organization. 
Table 2

Classification of Employees by Organizations

\begin{tabular}{lcc}
\hline Nature of the organization & Frequency & Percent \\
\hline Business & 76 & 47.5 \\
Service & 84 & 52.5 \\
Total & 160 & 100 \\
\hline
\end{tabular}

Source: Field Survey, 2019

Out of the total of 160 employees who took participation in this research as respondents, 76 employees were from business nature, 84 employees were from service nature organization. Here, respondents from both nature of organization were full time employees working there from last one year.

Table 3

Classification of Employees by Gender

\begin{tabular}{lcc}
\hline Gender & Frequency & Percent \\
\hline Male & 85 & 53.1 \\
Female & 74 & 46.3 \\
Others & 1 & 0.6 \\
Total & 160 & 100 \\
\hline
\end{tabular}

Source: Field Survey, 2019

Out of the 160 respondents, both male and female were respondents. The sample comprised $53.1 \%$ $(n=85)$ of male employees compared to $46.3 \%(n=74)$ of female employees and rest $0.6 \%$ was represented by others group. Majority of the respondents were male in this survey questionnaire.

Table 4

Classification of Employees by Age

\begin{tabular}{lcc}
\hline Age & Frequency & Percent \\
\hline Less than 25 years & 91 & 56.9 \\
25-35 years & 63 & 39.4 \\
35-45 years & 3 & 1.9 \\
More than 45 years & 3 & 1.9 \\
Total & 160 & 100 \\
\hline
\end{tabular}

Source: Field Survey, 2019

The age group of respondents has been categorized into four groups. Out of 160 respondents, 91 respondents fell within the age group of less than 25 years representing $56.0 \%, 63$ respondents fell within the age group of 25 to 35 years representing 39.4\%, 3 respondents fell within the age group of 35 to 45 representing $1.9 \%$, and rest 3 respondents fell within the age group of above 45 years representing $1.9 \%$.

Table 5

Classification of Employees by Education

\begin{tabular}{lcc}
\hline Highest level of education & Frequency & Percent \\
\hline Under Graduate & 64 & 40 \\
Graduate & 67 & 41.9 \\
Post Graduate & 29 & 18.1 \\
Total & 160 & 100 \\
\hline
\end{tabular}

Source: Field Survey, 2019 
Majority of the respondents (67) had obtained graduate degree representing $41.9 \%, 40 \%$ of the respondents had obtained an under-graduate degree and 29 respondents had completed post-graduate degree representing only $18.1 \%$ out of 160 respondents.

Table 6

Classification of Employees by Job Tenure

\begin{tabular}{lcc}
\hline Job Tenure & Frequency & Percent \\
\hline Less than 1 year & 80 & 50 \\
1-5 years & 57 & 35.6 \\
$5-10$ years & 17 & 10.6 \\
$>10$ years & 6 & 3.8 \\
Total & 160 & 100 \\
\hline
\end{tabular}

Source: Field Survey, 2019

Out of 160 respondents, 80 employees had been working in that bank for less than 1 year representing $50 \%, 57$ employees had been working in the same bank for 1 to 5 years representing 35.6\%, 17 employees had been working in the same bank for 5 to 10 years representing $10.6 \%$ and $3.8 \%$ had job tenure of 10 years. Majority of the employees had job tenure of less than 1 year.

Table 7

Classification of Employees by Position

\begin{tabular}{lcc}
\hline Position & Frequency & Percent \\
\hline Assistant & 88 & 55 \\
Officer & 39 & 24.4 \\
Manager & 33 & 20.6 \\
Total & 160 & 100 \\
\hline
\end{tabular}

Source: Field Survey, 2019

Out of 160 respondents, 80 respondents were in assistant level representing 55\%, 39 respondents were in officer level representing $24.4 \%$ and rest 33 respondents representing $20.6 \%$ were from manager level from three different organizations.

Table 8

Hours worked by employees per week

\begin{tabular}{lcc}
\hline Hours worked/week & Frequency & Percent \\
\hline $0-20$ hours & 24 & 15 \\
20-40 hours & 41 & 25.6 \\
$40-50$ hours & 83 & 51.9 \\
More than 50 hours & 12 & 7.5 \\
Total & 160 & 100 \\
\hline
\end{tabular}

Source: Field Survey, 2019

Out of 160 respondents, 24 responded that they work less than 20 hours a week, 41 responded that they work 20-40 hours in a week, majority i.e. 83 respondents responded that they work 40 to 50 hours in a week and 12 responded that they work more than 50 hours a week. 
Table 9

Time spend on travelling to and from work

\begin{tabular}{lcc}
\hline Travelling time & Frequency & Percent \\
\hline Less than 30 minutes & 50 & 31.3 \\
30 - 60 minutes & 87 & 54.4 \\
1 - 2 hours & 17 & 10.6 \\
More than 2 hours & 6 & 3.8 \\
Total & 160 & 100 \\
\hline
\end{tabular}

Source: Field Survey, 2019

Out of 160 respondents, majority of 87 respondents responded that they spend 30 to 60 minutes travelling to and from work representing $54.4 \%, 50$ respondents spend less than 30 minutes travelling to and from work representing $31.3 \%, 17$ respondents spent 1 to 2 hours travelling to work representing $10.6 \%$ and rest 6 respondents spent more than 2 hours travelling to and from work which is $3.8 \%$ of total respondents.

Table 10

Correlation Analysis among Variables

\begin{tabular}{lcc}
\hline & FWA & Work-life Balance \\
\hline FWA & 1.000 & $0.574^{* *}$ \\
Work-life Balance & & 1.000 \\
\hline
\end{tabular}

Table 10 shows the correlation matrix between the dependent variable and independent variables where flexible working arrangement is independent variable and work-life balance is dependent variable. The value of Pearson Correlation equal 0.574, which indicates a fair correlation between FWA and work-life balance. Result also indicates a positive relationship between FWA and work-life balance. The corresponding $\mathrm{p}$-value is 0.000 which signifies significant relationship between FWA and Work-life balance.

Table 11

Regression Analysis of Work-life Balance

\begin{tabular}{lcccc}
\hline Model & Un standardized Coefficients & t & Sig. \\
\hline & B & Std. Error & & \\
(Constant) & 1.49 & 0.251 & 5.943 & 0.000 \\
Flexible Working Arrangements & 0.587 & 0.067 & 8.822 & 0.000 \\
\hline
\end{tabular}

Dependent variable: Work-life Balance

Table 11 shows the relationship between flexible working arrangements and the work-life balance of employees. The regression coefficient of 0.587 indicates a positive relationship between them. Here, a t-value of 8.822 with a corresponding p-value of 0.000 shows that there is a significant relationship between flexible working arrangements and work-life balance. Thus, FWA impacts the work-life balance of employees positively.

\section{Conclusion and Implication}

From the overall results and findings, it is found that there is a directly proportional relationship between flexible working arrangements and work-life balance. It is found that employees feel that FWA is the right kind of system for their kind of job and they prefer FWA at work. FWA is found to have a positive impact on the performance of employees as employees feel and agree that FWA makes them more responsible 
as they can manage time at work and at the same time can fulfill personal commitments. Additionally, it also increases the quality of work and productivity leading to the improvement in performance.

This research adds to the existing literature that studies the impact of FWA on employees job outcome. McNall, Masuda, and Nicklin (2009) found that the availability of flexible work arrangements such as flextime and compressed workweek seems to help employees experience greater enrichment from work to home, which, in turn, is associated with higher job satisfaction and lower turnover intentions. Similarly, De Menezes and Kelliher, (2011) highlighted that HRM practices that increase workforce flexibility may boost productivity and innovativeness, and ultimately could lead to increased financial performance, which can manifest itself as increased profitability. Moreover, Beauregard and Henry (2009) found organizational commitment, reduced turnover intentions, and increased job satisfaction apply only if the employees perceive that the usability of flexibility is to increase their control over time. Achievement of inside the work and outside the work responsibilities leads to finding a work-life balance,

As professional employees need to work long hours and according to the nature of their job, there requires long-term commitment, sometimes may overrun into their personal lives. E-mail, messenger, and cell phones are providing too much information and accordingly, there are more work demands. Nowadays, people are busy even in their travel, on vacation, on planes, and even in private hours, employees can be interrupted by work demands. Considering this development, many organizations are initiating steps to offer more flexible work schedules. They are concerned to protect employees' free time and to more productively use employees' work time.

The number of flexible policies within the workplace should reflect a family-friendly working environment, and accommodate employees' needs. As flexibility gives an employee the ability to control when, where, and how much time do they work, it contributes to improvement in the allocation of work and life responsibilities. It is a valuable way to relieve the pressures and conflicts of trying to balance work and non-work activities. Hence, organizations should revisit their working schedule and do some research if the introduction and implementation of FWA can bring balance between the work and the personal life of an individual.

\section{References}

Almer, E. D., \& Kaplan, S. E. (2002). The effects of flexible work arrangements on stressors, burnout, and behavioral job outcomes in public accounting. Behavioral Research in Accounting, 14, 1-34.

Bailyn, L., Rayman, P., Bengtsen, D., Carre, F., \& Tierney, M. (2001). Fleet financial and radcliffe explore paths of work/life integration. Journal of Organizational Excellence,

Beauregard, T. A., \& Henry, L. C. (2009). Making the link between work-life balance practices and organizational performance. Human Resource Management Review, 9-22.

Berker, E.,Morley, M.J.,Tiernan,S.,Purtill,H.,\&Parry,E.(2017). On the uptake of flexible working arrangements and the association with human resource and organizational performance out comes. European Management Review, 14(2), 165-183.https://doi.org/10.1111/ emre.12103

Cooper, C., \& Burke, R. (2008, December). The long work hours culture. (A. Craven, Interviewer) Emerald Group Publishing Limited.

Darley, L. (2017, September). The future of work: Flexible work arrangements. Retrieved from Forbes: https://www.forbes.com/sites/forbescoachescouncil/2017/09/21/the-future-of-work-flexible-workarrangements/\#61990ce0ff3f

De Menezes, L. M., \& Kelliher, C. (2011). Flexible working and performance: A systematic review of the evidence for a business case. International Journal of Management Reviews, 13(4), 452-474.

Flexible Work Arrangements. (2017, January 16). Retrieved from Inc: https://www.inc.com/soniathompson/the-essential-martin-luther-king-jr-leadership-lesson-all-good-leaders-should-ma.html

Ghimire, B. (2017). Demographic Analysis of Nurses' Organizational Commitment With Demographic Analysis of Nurses' Organizational Commitment With Reference To 
Nepal. International Journal of Technical Research \& Science, 2 (January), 772-777.

Ghimire, B. (2020). The Mediating Role of Trust in Management on Job Satisfaction and organizational Commitment. Pravaha Journal; A Journal of Management, 25(1), 43-52 https://doi.org/10.3126/ pravaha.v25i1.31932

McNall, L. A., Masuda, A. D., \& Nicklin, J. M. (2009). Flexible work arrangements, job satisfaction, and turnover intentions: The mediating role of work-to-family enrichment. Journal of Psychology: Interdisciplinary and Applied, 144(1), 61-81. https://doi.org/10.1080/00223980903356073

Nepali, D. P. (2018). Balancing work-life and family life: Problems and remedies. Pravaha Journal; A Journal of Management, 217-232.

Thevanes, N., \& Mangaleswaran, T. (2018). Relationship between work-life balance and job performance of employees. IOSR Journal of Business and Management, 20(5), 11-16. doi:10.9790/487X-2005011116 
Issue 1 May/June 2020 - 